\title{
ASSESSMENT OF THE IMPACT OF INCOME INEQUALITY ON ECONOMIC GROWTH IN RUSSIAN REGIONS \\ Rogneda Vasilyeva ${ }^{1}$, Oleg Mariev $^{2}$, Elena Ignatieva $^{3}$, Alla Serkova ${ }^{4}$
}

\begin{abstract}
Inequality in the distribution of income of the population has a certain impact on different aspects of the economic and socio-cultural development of countries and regions. This inequality arises due to a number of factors as the current nature of the production specialization, the availability of production and economic infrastructure, the achieved level of development of the social sphere, socio-cultural, demographic, and other factors. The main objective of this study is to assess the nature and extent of the impact of income inequality in the Russian regions for the subsequent justification of the directions of socioeconomic development. We conducted an econometric analysis of the impact of intraregional income inequality (the Gini coefficient), fixed capital investment per capita, and average per capita consumer spending on one of the main indicators of regional economic growth (GRP) per capita was carried out. The model is based on panel data for the period 2012-2018 for 85 regions of the Russian Federation. The results of the study confirm two of three hypotheses. As prospects for further research, it is proposed to consider the impact of inequality in the distribution of household income on economic growth for different groups of regions, including resource-type regions and regions with a predominance of manufacturing industries, as well as for leading regions and regions with a relatively low level of socio-economic development.
\end{abstract}

JEL Classification Numbers: O15, I24, DOI: https://doi.org/10.12955/peb.v2.261

Keywords: region, income inequality, economic growth, physical capital, human capital.

\section{Introduction}

Inequality in the distribution of income of the population has a certain impact on different aspects of the socio-economic development of countries and regions. The existence of such inequality in the regions of the Russian Federation can be judged based on the Federal State Statistic Service data. For example, in 2019 in Moscow, the share of the population with an average per capita income of less than 7,000 thousand rubles was 0.4 percent, with incomes of more than 60,000 - 14.3 percent, and in the Tyva Republic, these indicators were 14.3 percent and 0.9 percent, respectively. The average per capita income of the population in 2019 of the Yamalo-Nenets Autonomous Okrug was 5 times higher than the corresponding indicator in the Ingushetia Republic and 4.5 times higher in the Kalmykia Republic. This anecdotal evidence reflects a significant interregional differentiation of the population's income. Intraregional inequality can be judged by the values of the Gini coefficient, which in Moscow and the Yamalo-Nenets Autonomous Okrug exceeded the average Russian level (0.411) and was 0.415 and 0.437 , respectively, and in a number of regions, in particular in the Republics of Ingushetia and Karelia, was lower than the average Russian level -0.334 and 0.341 , respectively.

A number of reasons cause this inequality, including historical and genetic features of the development of territories - such as the established specialization of production, the availability of production and economic infrastructure, the achieved level of development of the social sphere, socio-cultural, demographic, and etc. There are a number of publications devoted to the study of income inequality and the factors that affect it in different countries (Perugini et al.,2008; Ferreira et al., 2011; Oancea et al., 2017). Among Russian publications, one can single out the research of Zubarevich (2010) on the causes and consequences of differentiation of Russian regions by the level of population income and measures of human capital growth in problem regions. Goncharova (2019) investigates the nature of the influence of factors that characterize the socio-demographic structure of the population on the regional differentiation of population income. Kostenko (2018) examines the trends and consequences of income inequality in Russia, justifying the need for fiscal and social policy changes. The influence of economic, demographic, and infrastructural factors on intraregional inequality of income distribution in the regions of the Russian Federation (the Gini coefficient) was considered by Groznykh et al. (2020). The main

\footnotetext{
${ }^{1}$ Graduate School of Economics and Management, Ural Federal University, Yekaterinburg, Russian Federation, ronav999@gmail.com.

${ }^{2}$ Graduate School of Economics and Management, Ural Federal University, and Institute of Economics of the Ural Branch of the Russian Academy of Sciences, Yekaterinburg, Russian Federation,

o.s.mariev@urfu.ru

${ }^{3}$ Institute of Economics of the Ural Branch of the Russian Academy of Sciences, Yekaterinburg, Russian Federation, elen_i99@mail.ru

${ }^{4}$ Graduate School of Economics and Management, Ural Federal University, and Institute of Economics of the Ural Branch of the Russian Academy of Sciences, Yekaterinburg, Russian Federation, muccio@bk.ru
} 
objective of this study is to assess the nature and extent of the impact of income inequality in the Russian regions on one of the main indicators of economic growth - gross regional product (GRP) per capita for the subsequent justification of the directions of socio-economic development.

\section{Literature Review}

Existing studies justify different points of view and conclusions about the relationship between income inequality and economic growth for countries and regions. The most commonly used indicators for measuring this inequality are the Gini coefficient, dispersion, coefficient of variation, Atkinson, Dalton, Teil, and Herfindahl indices, while the gross domestic product (GDP), gross regional product per capita (GRP), labor productivity growth, output, and others are used as indicators of economic growth in countries and regions. Galor (2000) considers the evolution of the role of income distribution on economic growth. He notes that this process is characterized by an endogenous transition from the dominance of physical capital as the main engine of economic growth to a gradual increase in the importance of human capital accumulation. According to the classical approach, income inequality contributes to the accumulation of physical capital. It is the main source of economic growth in the early stages of industrialization since resources are directed to benefit individuals whose marginal propensity to save is higher at the later stages of the industrial development of countries, the importance of human capital as the main engine of economic growth increases. As the income of the population increases, the adverse effects of inequality in the accumulation and growth of human capital are leveled, and the impact of income inequality on the process of economic growth becomes insignificant. Thus, the author concludes that inequality stimulates economic growth at those stages of development where the accumulation of physical capital is the main engine of economic growth, while equality promotes economic growth at those stages of development where the accumulation of human capital is the dominant engine of economic growth. The author emphasizes the importance of building unified models of growth and development that could explain the historical evolution of the role of inequality in the development process of countries.

Shin (2012) examines the relationship between the Gini coefficient and the economic growth rate based on the Kuznets curve and convergence theory. The author concludes that income inequality in developing countries slows down economic growth, and income inequality in rich countries stimulates economic growth. In other words, income inequality has a negative impact on economic growth at an early stage of economic development and a positive impact on economic growth in the transition to sustainable development.

Fleisher et al. (2010) show the dependence of economic growth indicators on regional differences in physical, human, and infrastructure capital and foreign direct investment flows in the provinces of China. The authors estimate the production functions for different provinces. The resources include physical capital and two categories of labor: first,less-educated workers who do not have a secondary school education; second, educated workers who have a secondary school education or higher. The paper proposes and proves the hypothesis that provinces with a relatively large proportion of highly educated workers benefit from developing and using new production technologies and borrowing technologies from provinces with a higher level of technology. The authors also note that high economic growth in China has brought unequal benefits to its provinces and regions. China has not only one of the highest rates of economic growth but also one of the highest levels of regional income inequality in the world.

Madsen et al. (2018) assess the impact of income inequality on economic growth using factors such as savings, investment, education, and knowledge production. They conducted the empirical study on the basis of a panel data set for 21 OECD countries for 142 years (the period 1870-2011). They concluded that inequality has a significant negative impact on growth in countries with an underdeveloped financial and credit system. The main reason is that low-income households have limited access to credit facilities, and the constraints of the credit market affect the poor more than the rich. The underdevelopment of financial markets hinders the development of entrepreneurship and innovation. However, inequality has little impact on growth rates in countries with highly developed financial and credit systems.

Malkina (2014) tests the modified hypothesis of Simon Kuznets about the relationship between the level of economic development and the degree of income differentiation in the regions of the Russian Federation by the method of correlation and regression analysis. She uses the real GRP, reduced to the prices of 1998, as an indicator of the level of economic development. As a result of the regression 
analysis, 4 direct relationships were found, most reliably described by second-order polynomials, namely: between the real income per capita in the region and the Gini index (coefficient of determination 0.744), between the real income per capita in the region and the coefficient of funds (coefficient of determination 0.785), between the real GRP per capita in the region and the Gini index (coefficient of determination 0.382), between the real GRP per capita in the region and the coefficient of funds (coefficient of determination 0.364).

\section{Data and Methodology}

Based on the literature review, we strive to test the following hypothesis in the research. First, we assume that income inequality has a negative impact on economic growth, as it hinders the formation and development of human capital, increases the burden on the social sphere, contributes to the strengthening of social tension and the growth of crime; second, we suggest that income inequality has a positive impact on economic growth since the formation of a high-income population group can provide an influx of investment in the economy, including in the development of highly technological industries. The third hypothesis considers that inequality in the income of the population does not impact significantly economic growth since the benefits of the already formed human capital are realized at the stage of industrial development.

To test these hypotheses, we conduct an econometric analysis of the impact of inequality in the distribution of household income and a number of other factors on GRP per capita as one of the main factors of economic growth in the regions. The model is based on panel data for the period 2012-2018 for 85 regions - subjects of the Russian Federation. The choice of the observation period was determined by the completeness and relative uniformity of the necessary data. The database was developed based on the Federal State Statistic Service data for the corresponding period of time. The choice of independent variables was based on the analysis of literary sources and was determined by the possibility of obtaining the necessary data from official statistics. The dependent variable and independent variables included in the model are shown in table 1.

\begin{tabular}{|c|c|c|}
\hline Indicator name & Measure unit & Designation \\
\hline \multicolumn{3}{|l|}{ Dependent variable: } \\
\hline Gross regional product per capita & roubles & grpud \\
\hline \multicolumn{3}{|l|}{ Independent variables: } \\
\hline $\begin{array}{l}\text { Number of university students per } 10,000 \\
\text { population }\end{array}$ & units & stud \\
\hline Investments per capita & roubles & invud \\
\hline Scientific and technical expenses per capita & roubles & innud \\
\hline Gini coefficient & & jinni \\
\hline Percentage of the employed population & percent & empl \\
\hline Average per capita consumer spending & roubles & $\exp$ \\
\hline
\end{tabular}

\section{Results and Discussion}

The parameters of the econometric model are represented in Table 2. The model was estimated by the ordinary least squares method. The coefficient of determination is 92 percent. According to the Fisher test, the regression is statistically significant. Tests for heteroskedasticity and autocorrelation are negative. Three significant factors were identified.

The analysis shows that investment ("physical capital") is one of the main factors that have a significant impact on economic growth in the Russian regions. According to the model, the growth of income inequality stimulates the growth of GRP. The reason for this phenomenon may be the increase in the rich part of the population, who are actual and potential investors.

The average per capita consumer spending of the population also stimulates economic growth due to the growth of consumption by the "rich" group. At the same time, the negative impact of the growth in the number of students in higher education institutions suggests that the formed human capital is not fully realized. The reasons are that some graduates do not work in their specialty, the distribution of specialists by field of activity is not optimal enough due to the difference in wages, etc. The factor "Scientific and technical expenses per capital" as an indicator of innovation activity did not impact significantly GRP, 
although this effect is positive. According to the results of the study, we can conclude that we partially confirm the first and second hypotheses.

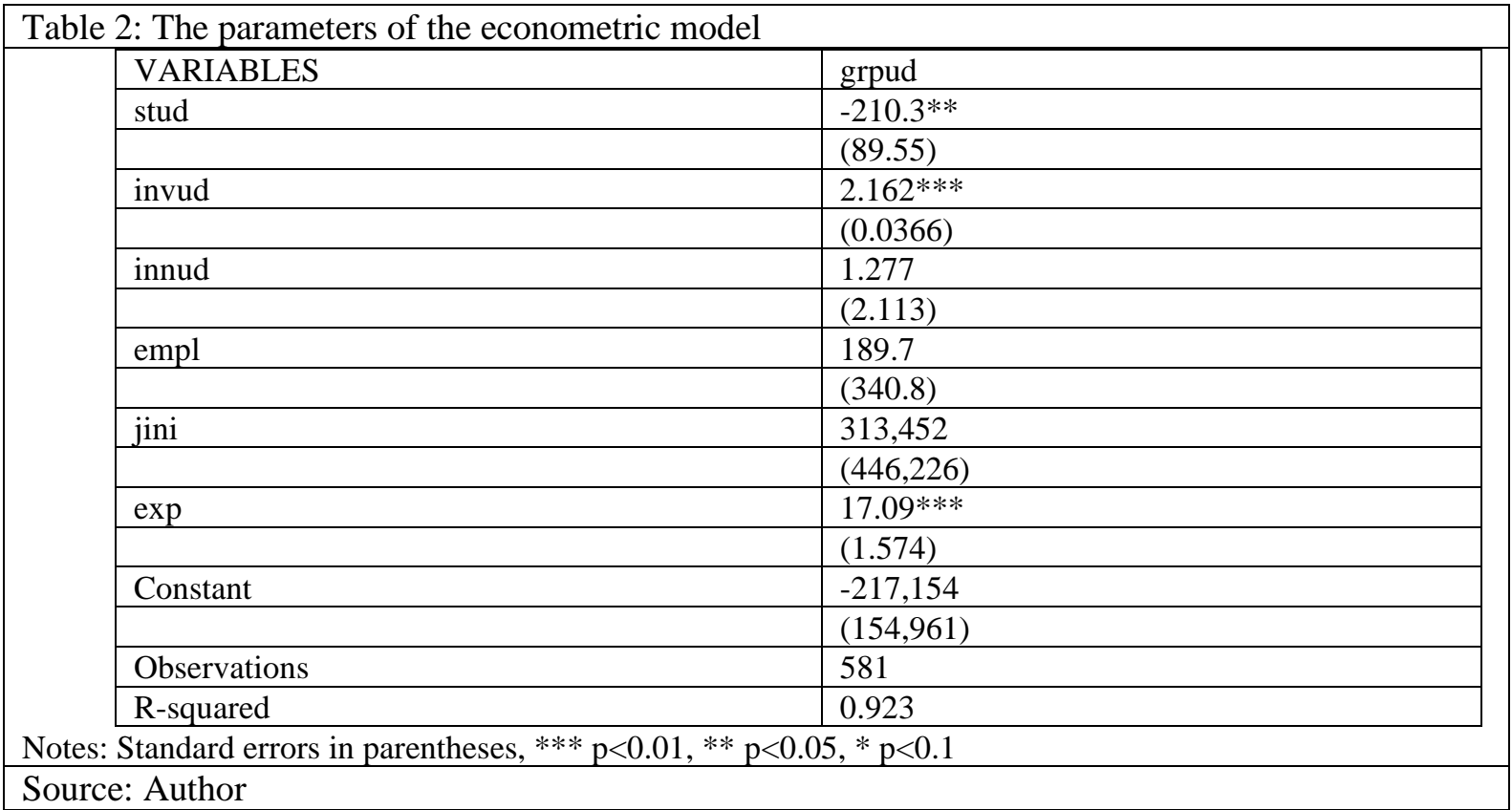

\section{Conclusion}

The results of the study indicate a partial confirmation of two out of three hypotheses. At the present stage, the main factor of economic growth in the regions of the Russian Federation is an investment. However, the preferred direction of their attraction is not the growth of inequality in the income of the population but the use of other sources - the savings of individuals and legal entities, pension funds, public-private partnerships, foreign direct investment, and so on. It is necessary to increase and optimize the use of human capital, first of all highly qualified specialists, which is a necessary condition for the growth of innovation activity as a factor of GRP growth.

The heterogeneity of the Russian regions explains the fact that the initial hypotheses were not fully confirmed in terms of the level of socio-economic development, the nature of specialization, etc.

It is possible to build a typology of regions based on a number of features. For more detailed testing of hypotheses, taking into account the specifics of economic growth in the Regions of the Russian Federation, it is necessary to study further the impact of inequality in the distribution of income of the population on economic growth in regions of different groups-with a predominance of mining or manufacturing industries, with other types of specialization. It is advisable to conduct such an analysis for leading regions and regions with a relatively low level of socio-economic development and the evolution of the impact of income inequality on economic growth at different stages of the economic cycle. The results of this analysis will allow us to justify the directions of economic growth for different territories in more detail.

\section{References}

Ferreira, Francisco H. G. and Gignoux, Jérémie, (2011). The Measurement of Inequality of Opportunity: Theory and an Application to Latin America (December 2011). Review of Income and Wealth, Vol. 57(4), 622-657, doi:10.1111/j.14754991.2011.00467.x.

Fleisher B., Li H., Zhao M. Q. (2010). Human capital, economic growth, and regional inequality in China. Journal of development economics. Vol. 92 (2), 215-231.

Galor O. (2000) Income distribution and the process of development. European Economic Review. Vol. 44 (4-6), 706-712.

Goncharova K. S. (2019) Socio-demographic features of regional differentiation of income of the population of Russia. Corporate governance and innovative development of the economy of the North: Bulletin of the Research Center for Corporate Law, Management and Venture Investment of Syktyvkar State University. No. 4, 157-168, doi:10.34130/20704992-2019-4-157-168.

Groznykh R., Ignatieva E., Mariev O. \& Serkova A. (2020). The impact of economic, demographic, and infrastructural factors on income inequality and poverty in Russia. Proceedings of CBU in Economics and Business, 1, 70-75, doi:10.12955/peb.v1.21 
Kostenko O. V., Kostenko P. E. (2018) Inequality of income of the population in Russia: Level and trends of change. Bulletin of the VSU. Series: Economics and Management. No. 2, 90-95.

Madsen J. B., Islam M. R., Doucouliagos H. (2018) Inequality, financial development and economic growth in the OECD, 1870-2011. European Economic Review. Vol. 101, 605-624, doi:10.1016/j.euroecorev.2017.11/004.

Malkina M. Yu. (2014) Study of the relationship between the level of development and the degree of income inequality in the regions of the Russian Federation. The economy of the region. Vol. 2(38), 238-248. doi:10.17059/2014-2-23.

Oancea, B., Tudorel, A., Pirjol, D. (2017). Income inequality in Romania: The exponential-Pareto distribution. Physica A: Statistical Mechanics and its Applications. 469. 486-498, doi: 10.1016/j.physa.2016.11.094.

Perugini, C., Martino, G. (2008) Income Inequality within European Regions: Determinants and Effects on Growth. Review of Income and Wealth, Vol. 54 (3), 373-406, doi:10.1111/j.1475-4991.2008.00280.x.

Shin I. (2012) Income inequality and economic growth. Economic Modelling. Vol. 29 (5), 2049-2057.

Zubarevich N. V. (2010) Regions of Russia: Inequality, crisis, modernization. Independent Institute of Social Policy, PP. 160. 